\title{
ORGANIC FARMING AS A MEANS OF SUSTAINABLE AGRICULTURE PRACTICE IN INDIA
}

\author{
Pubali Hazarika \\ M.Phil, Research Scholar (Department of Economics), Dibrugarh University, \\ Dibrugarh, Assam, India
}

\begin{abstract}
An agriculture growth rate which enable the living things to meet their demand without harming the ecological equilibrium and putting the environment in endangerment is emphasized by sustainable agriculture. Organic farming is one among the several approach of production methods that are supportive of the environment and can meet the objectives of sustainable agriculture. Organic farming is one of the best alternative to avoid the ill effects of chemical farming. According to International Federation of Organic Agriculture Movement (IFOAM), 'organic agriculture' is a production system that sustains the health of soils, eco systems and people. India being rich in bio-diversity and the same time have high fertility status of the soil has vast opportunity to emerge as major supplies of organic products. Indian farmers have traditionally followed the principles of organic farming in their farm activities. Adoption of new technology in traditional farming and awareness among farmers can make them more productive. The study is based on secondary data. The findings of the study are that organic farming is environmentally sustainable and have large scope in India.
\end{abstract}

The paper focus on the understanding of the prospects and challenges of sustainable agriculture practice in India.

Key words: organic farming, sustainable agriculture, traditional farming, awareness.

Cite this Article: Pubali Hazarika, Organic Farming as a Means of Sustainable Agriculture Practice in India, International Journal of Management, 11(12), 2020, pp. 2074-2080.

http://iaeme.com/Home/issue/IJM?Volume=11\&Issue=12

\section{INTRODUCTION}

The concept of sustainable development is one of the most leading conversation among individuals in recent years. The origin of the term sustainability can be coined in German, Nachhaltigkeit being the original term used for sustainability meaning "sustained yield". It was used to signify never harvesting more than the forest can regenerate (Handbook of forestry 
1713) (1). The concept of sustainability has been changing over time. The most world widely prevailing definition of sustainable development is the definition given by Brundtalnd Report 1987, which states "sustainable development is the development that meets the needs of present generation without compromising the ability of future generation to meet their own needs." (2)

In order to accomplish the objectives of Sustainable Development nations can adopt sustainable agriculture practice. An agriculture growth rate, which enable the living things to meet their demand without harming the ecological equilibrium and putting the environment in endangerment is emphasized by sustainable agriculture. A precise meaning for sustainable agriculture is difficult to attain in a given time period, to some extent due to disagreement in standpoint among relevant groups. Ikerd (1993) defines sustainable agriculture as "capable of maintaining its productivity and usefulness to society over the long run. ... it must be environmentally-sound, resource-conserving, economically viable and socially supportive, commercially competitive, and environmentally sound" (p. 30) (3). Organic farming is one among the several approach of production methods that are supportive of the environment and can meet the objectives of sustainable agriculture. Organic farming is one of the best alternative to avoid the ill effects of chemical farming. International Federation of Organic Agriculture Movement (IFOAM), states 'organic agriculture' is a production system that sustains the health of soils, eco systems and people. It depends on environmental friendly processes that can be adapted to local conditions, rather than the use of inputs with catastrophic effects. Organic farming is a combination of traditional method, innovation and science which helps living things to live in a better environment. The Food and Agriculture Organization (FAO) defines organic farming as a holistic production management system which promotes and enhances agro-ecosystem health, including biodiversity, biological cycles, and soil biological activity.

\section{OBJECTIVES OF THE STUDY}

- To assess and evaluate the factors motivating farmers to adopt organic farming in India.

- To identify the constraints faced by the farmers in the adoption of organic farming in India.

\section{REVIEW OF LITERATURE}

From 1981 through 2002, 22-year field investigation were conducted at the "Rodale Institute" in Pennsylvania on conventional cropping, organic animal-based cropping and organic legume based cropping. Main crop used in the experiment were corn and soybean. They found that the yields for conventional system being significantly higher than the two organic system, but after transition period yields were similar for all system. Crop yields under drought conditions were significantly higher in the two organic system. They conclude that soil organic matter and nitrogen were higher in the organic farming system, providing many benefits to the overall sustainability of organic agriculture.

The organic movement in India has its origin in the work of A. Howard (1940), Agricultural Testament. It draws attention to the destruction of soil and deals with the consequences of it. It suggests methods to restore and maintain the soil fertility and productivity with the help of some examples.

P Ramesh, N. R. Panwar (2010) conducted a survey which concluded that organic farming provides high net profit as comparison to conventional farming due to high market value of organic products and low price for factor inputs.

Minhas and Sood [1994] also reported that the Organic farming was capable of sustaining higher crop productivity and improving soil quality and productivity by manipulating the soil properties on long-term basis. 
Johnson et al. (1995) observed in his study that yielding capacity of crops that used animal manures were high as it assists in refinement in soil quality.

(Pretty and Hine 2001) In a survey in African countries for sustainable agriculture initiatives shows that both crops yield and nutrition level improved over twenty years' time period.

\section{METHODOLOGY}

The present study is based on secondary data. Information from literature on the organic farming and the progress it has made both in India and abroad collected from the published sources like the websites of the European Union countries, International Federation of Organic Farming Movements (IFOAM), National Program On Organic Production (NPOP), Agricultural and Processed Food Products Export Development Authority (APEDA), books and reports is used for the preparation of the paper.

\section{PROSPECTS OF ORGANIC FARMING}

\subsection{The International Overview}

IFOAM- Organics International has been the global organic umbrella organization since 1972 According to the latest FiBL survey on certified organic agriculture worldwide, as of the end of the 2016; data on organic agriculture was available from 178 countries.

\subsubsection{Organic agricultural land}

There were 57.8 million hectares of organic agriculture land in 2016. The regions with largest area of organic agricultural land are Oceania (27.3 million hectare), and Europe (13.5 million hectare). The countries with most organic agricultural land are Australia (27.4 million hectare) followed by Argentina (3 MH) and China (2.3 MH).

\subsubsection{Producers of organic farming}

There were at least 2.7 million organic producers in 2016. Concentration of world's most organic producers are in Asia (40\%), followed by Africa (27\%) and Latin America (17\%). The countries with most producers are India (835,000), Uganda (210,352), and Mexico.

\subsubsection{Major crops under organic farming}

With a total of almost 10.6 million hectare $(\mathrm{MH})$, arable land constitutes $18 \%$ of the organic Agricultural land. Most of this category of land was used for cereals including rich (4.1 MH), followed by green fodder from arable land $(2.8 \mathrm{MH})$, Oilseeds $(1.3 \mathrm{MH})$, dry pulses and textile crops (0.5 MH each).

\subsubsection{Global market of organic farming}

Global market has increased to almost 90 billion dollars. In 2016, the countries with largest organic markets were United States (38.9 billion euros), Germany ( 9.7 billion euros) and France (6.7 billion euros). The largest single market was the United Nations (47\%) followed by European Union (37\%) and china (6\%).

\subsection{Organic Farming In India}

As per the available statistics, India's rank in terms of World's Organic Agricultural land was 9th and in terms of total number of producers was 1st as per 2018 data (Source: FIBL \& IFOAM Year Book 2018). 


\subsubsection{Area}

As on 31 March 2018, total area under organic certification process (registered under National Programme for Organic Production) is 3.56 million Hectare (2017-18). This includes 1.78 million ha $(50 \%)$ cultivable area and another 1.78 million Hectare $(50 \%)$ for wild harvest collection. In India, Madhya Pradesh has covered largest area under organic certification followed by Rajasthan, Maharashtra and Uttar Pradesh. During 2016, Sikkim became the first state in the world to convert its farmland into certified organic.

\subsubsection{Production}

India produced around 1.70 million MT (2017-18) of certified organic products which includes all varieties of food products namely Oil Seeds, Sugar cane, Cereals \& Millets, Cotton, Pulses, Medicinal Plants, Tea, Fruits, Spices, Dry Fruits, Vegetables, Coffee etc. The production is not limited to the edible sector but also produces organic cotton fiber, functional food products etc. Among different states, Maharashtra is the largest producer followed by Madhya Pradesh, Karnataka, Uttar Pradesh and Rajasthan. In terms of commodities sugar crop are the single largest category followed by oil seeds, Cereals and Millets, Fiber crops, Pulses, Medicinal, Herbal and Aromatic plants and Spices and Condiments.

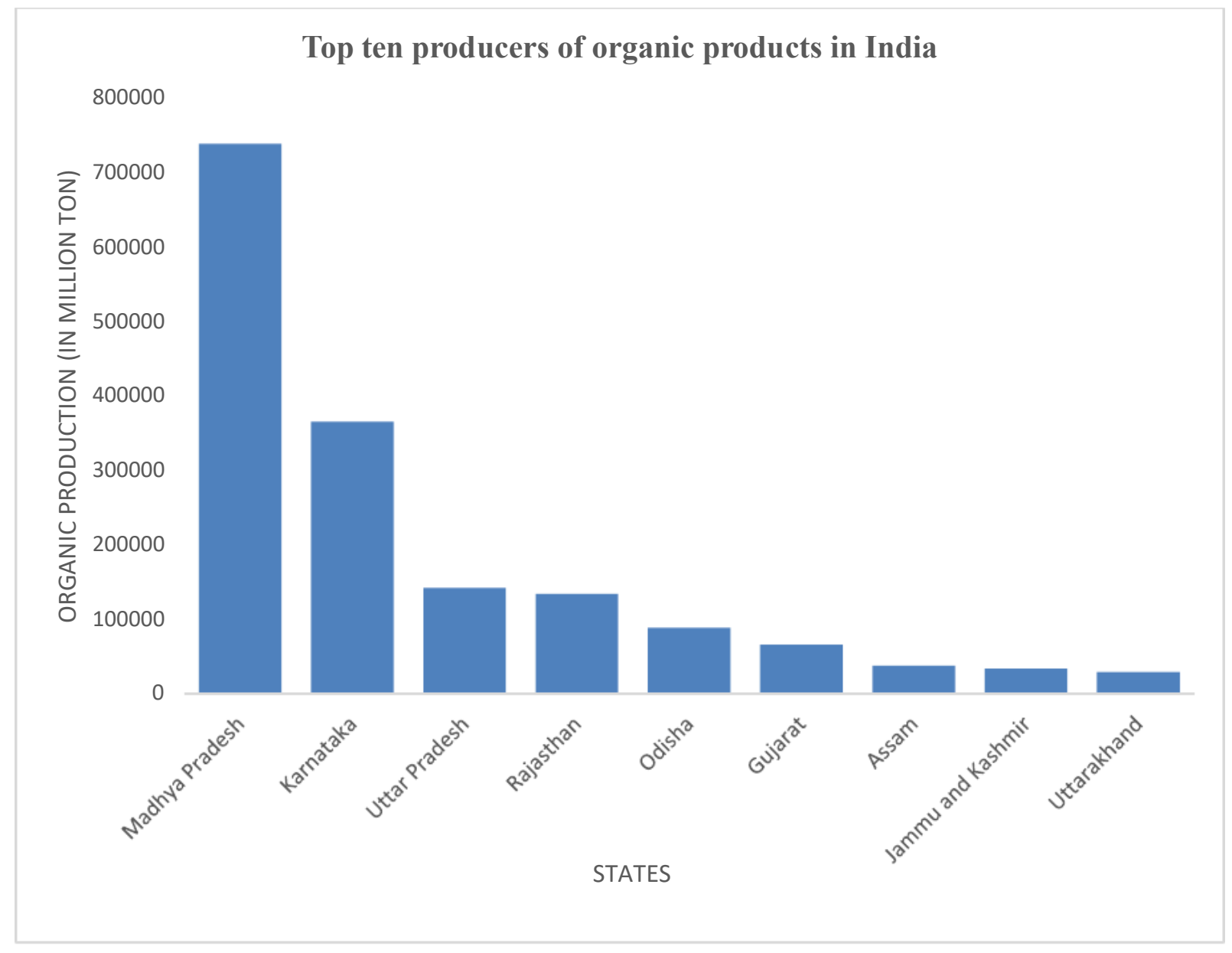

Figure 1

Source- National Programme for Organic Production (NPOP) statistics 2018-19 
Top ten organic crops grown in India in 2018-19

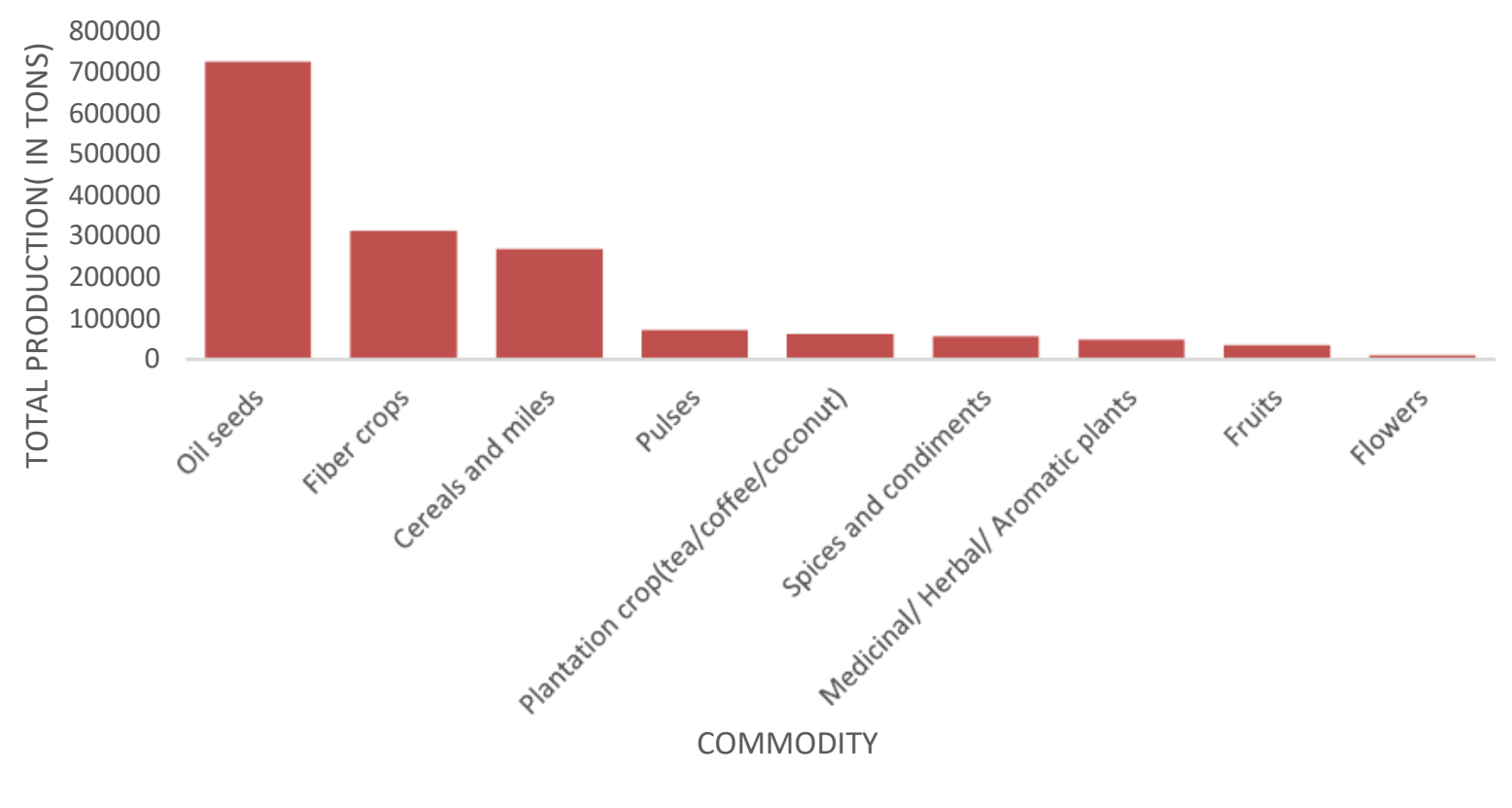

Figure 2

Source- National Programme for Organic Production (NPOP) statistics 2018-19

\subsubsection{Exports}

The total volume of export during 2017-18 was 4.58 lakh MT. The organic food export realization was around INR 3453.48 crores (515.44 million USD). Organic products are exported to USA, European Union, Canada, Switzerland, Australia, Israel, South Korea, Vietnam, New Zealand, Japan etc.

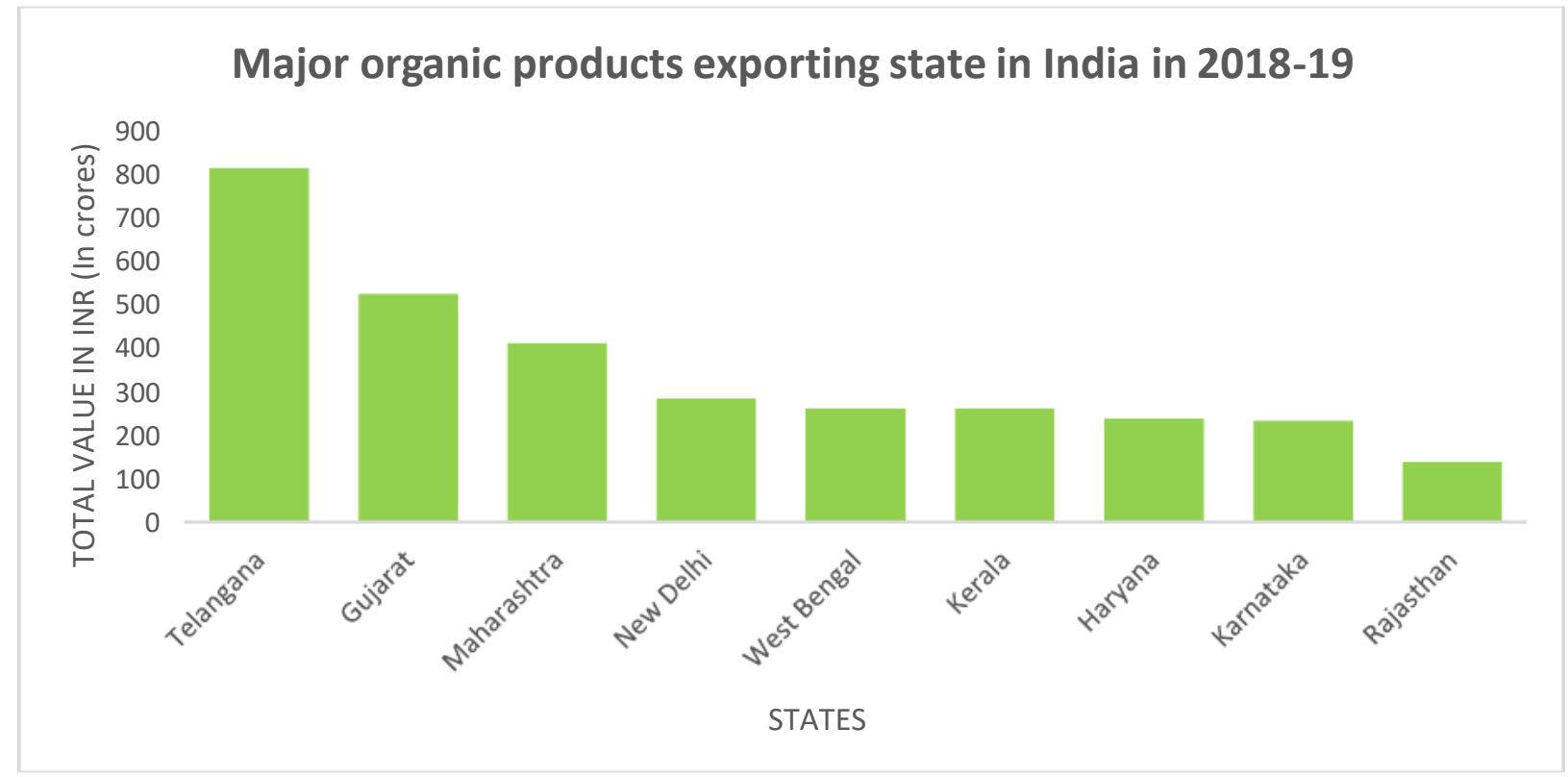

Figure 3

Source- National Programme for Organic Production (NPOP) statistics 2018-19 


\section{RELEVANCE OF ORGANIC FARMING IN INDIA}

Organic farming is very native to India. Indian farmers were practicing organic farming since ages. In most of the part of India, the entire agriculture was practiced using organic techniques, where the fertilizers, pesticides, etc., were obtained from plant and animal products which is regarded as traditional farming of India. The damages caused by the conventional farming arises the demand to adopt organic farming in India. Numerous small farmers have been practicing organic farming in India, however, since they are unaware of the market opportunities they are not able to reap the benefits of organic farming. Given below are some of the factors to adopt organic farming in India.

- Low investment: Organic farming is economical compare to chemical farming. We can also produce organic fertilizers and pesticides locally, which reduces the cost of production.

- Less dependence on moneylenders: In rural India, moneylenders still play a crucial role in advancing loans to the farmers. Moneylenders charges very high rate of interest compare to institutional credit advances by bank. Since organic farming demands less investment due to which farmers don't need to get in debt trap

- Traditional knowledge: As in India, most of the farmers in rural area have abundance of traditional knowledge, which is not much useful in chemical farming. We can make use of it in the development of organic farming.

- Employment Opportunities: -According to many studies, organic farming is a laborintensive farming. India being the second most populous country have abundance of cheap labor, which can be used in organic farming that will help in reducing disguised unemployment in agriculture sector.

\section{CONSTRAINTS OF ORGANIC FARMING IN INDIA}

Though India has the highest number of organic farmers across the world, Indian farmers failed to compete with its contemporary countries. Organic farmers have to face numerous constraints in terms of poor policy measures, rising input costs and limited market opportunity in the country. Government have not taken any serious policy measures to promote organic agriculture in India.

- Lack of Awareness: - India is still a agro based economy. The main occupation for people in rural India is agriculture. But rural farmers are unaware or have vague idea about the increasing demand for organic products in international market.

- High Input Costs: - The small and marginal farmers in India have been practicing a sort of organic farming in the form of the traditional farming system. Most of the farmers use pesticides and fertilizers which are available locally and environment friendly. But due to certification of organic products, the input cost of production has been increasing rapidly making it difficult for small framers to adopt organic farming.

- Lack of Financial Support: - No financial support is being provided in India as compare to advance countries. Neither central nor state government have taken any imitative to lend financial incentive to farmers for growing organic products. The promotion and marketing of organic farming is not even in the scenario of any policies of the government.

- Multiple certification systems: - Even as farmers are struggling to find a better market, the existing certification systems for organic food are making things difficult for them. The certification process consumes lot of time and very expensive which discourages the farmers to go for organic cultivation. It is important to eliminate confusion over 
multiple certification systems and multiple ministries regulating organic production and sales

- Shortage of Biomass: -Many experts and well-informed farmers are not sure whether all the nutrients with the required quantities can be made available by the organic materials. There is lack of bio mass production which is needed for organic farming.

\section{CONCLUSION}

The ill effects of the conventional farming system are felt in India in terms of the unsustainability of agricultural production, environmental degradation, and health and sanitation problem. India has not able to avail the benefits of organic farming and is fall behind than developed nations in terms of the adoption of organic farming. Financial support by governments (Central, state and lower level bodies) is very crucial to promote organic farming. Government should provide subsidies for organic cultivation. Market development for the organic products is an important factor to promote domestic sales. To increase the awareness of the farmers and consumers, a robust campaign to highlight the benefits of organic farming against the conventional system is needed. There is need for establishing credible, affordable and easily accessible certification facilities in the country.

\section{KEY NOTES}

(1) Hans Carl Von Carlowitz (1645-1747)

(2) World Commission on Environment and Development's 1987 Brundtland report 'Our Common Future'.

(3) Ikerd (1993)

\section{REFERENCES}

[1] Organic farming policies and prospects- S Dabbert, AM Haring, R Zanoli (2004).

[2] Environmental impacts of organic farming in Europe, M Stolze, A Piorr, AM Häring, S Dabbert -2000 .

[3] Organic Farming and sustainable Rural Development: A Multifaceted and Promising ConvergencePatrizia Pugliese

[4] A Howard, An Agri Testments, oxford university press, 1940.

[5] https://www.sciencedirect.com/science/article/pii/S0308521X00000603\#BIB27

[6] Rejendra P (2007) Organic Farming: A Fresh Thrust Needed, the Analyst Special Issue, The Icfai University Press pp. 47-48. Internet Source: www. Google.com, www.yahoo.com 